\title{
Increasing Bending Strength of Porcelain Stoneware via Pseudoboehmite Additions
}

\author{
Omar Aguilar-García, ${ }^{1}$ Rafael Lara-Hernández, ${ }^{1}$ Azucena Arellano-Lara, ${ }^{2}$ \\ José L. Gil-Vázquez, ${ }^{1}$ and Jaime Aguilar-García ${ }^{1}$ \\ ${ }^{1}$ Departamento de Ingeniería Industrial, Instituto Tecnológico de Morelia, Avenida Tecnológico 1500, Col. Lomas de Santiaguito, \\ 58120 Morelia, MICH, Mexico \\ ${ }^{2}$ Departamento de Cerámica, Instituto de Investigaciones Metalúrgicas, Universidad Michoacana de San Nicolás de Hidalgo, \\ Apdo. Postal 888, 58000 Morelia, MICH, Mexico
}

Correspondence should be addressed to Omar Aguilar-García; omarag@mail.com

Received 12 October 2013; Revised 3 March 2014; Accepted 3 April 2014; Published 28 April 2014

Academic Editor: Keizo Uematsu

Copyright ( 2014 Omar Aguilar-García et al. This is an open access article distributed under the Creative Commons Attribution License, which permits unrestricted use, distribution, and reproduction in any medium, provided the original work is properly cited.

\begin{abstract}
Pseudoboehmite nanoparticles synthesized through the desulfation of $\mathrm{Al}_{2}\left(\mathrm{SO}_{4}\right)_{3}$ were used to investigate the reinforcement of commercial porcelain stoneware. Fractured specimens investigated by SEM suggest that the added pseudoboehmite precursor generated a nanometric primary mullite phase dispersed in the porcelain glassy phase that limited and stopped the intergranular crack propagation. The porcelain modulus of rupture increased twice the value of the modulus of rupture (108 MPa) as compared with that samples without pseudoboehmite additions. Pseudoboehmite also led to increased densification of porcelain stoneware bodies up to $1250^{\circ} \mathrm{C}$ as shown by thermodilatometry data.
\end{abstract}

\section{Introduction}

A high volume of porcelain stoneware factories installed around the world have a typical $40-50 \mathrm{wt} \%$ kaolinitic clay, $35-45 \mathrm{wt} \%$ feldspar, and $10-15 \mathrm{wt} \%$ quartz sand composition. Such material is characterized by its high technological properties, like low water absorption $(<0.5 \%)$ and high bending strength $(>35 \mathrm{MPa})$. After firing, porcelain stoneware shows a typical matrix that consisted of mullite crystals embedded in the glassy phase that holds the coarse quartz particles. Mullitization, a controversial issue, has been studied in the literature for diverse ceramic systems with a view to strengthen the ceramic body. In fact, Zoellner's [1] theory on the strength of porcelain defines the nature of the mullite as a key phase responsible for the mechanical strength. It appears that generating the correct amount of properly sized mullite is vital in achieving the desired strength. Furthermore, the dispersionstrengthening hypothesis of porcelains proposes that the dispersed particles limit the size of Griffith flaws, leading to increased strength [2]. Strength is a function of the volume fraction of the dispersed phase at low volume fractions, while at high volume fractions the strength is dependent on both the volume fraction and the particle size of the dispersed phase. It has also been extensively reported in the literature [3] that the improvement in mechanical strength of porcelains arises from a prestressing effect whereby the quartz is under the tensile stress, and consequently, the glassy matrix surrounding the quartz grains is under a compressive stress.

Primary mullite first occurs as derived from kaolinite reaction series in porcelain compositions heated to around $1000^{\circ} \mathrm{C}$. Secondary mullite appears at higher temperature after molten feldspar dissolves clayey phases. In some porcelain systems, tertiary mullite has also been reported [1] as a result of a solution precipitation process from an alumina rich phase. Kaolin and gibbsite as well as synthetic mullite were added by Zanelli et al. [4] to porcelain stoneware to enhance mechanical properties. They found that though the mullite content in the porcelain body increased significantly, the physical and technological properties did not always increase proportional to the mullite content. Boehmite can 
be a source of nanosized alumina and presumably will make porcelain more reactive and strong in both green and fired states. The influence of boehmite gel additions on the green and sintered properties of alumina porcelain systems was investigated by Belnou et al. [5]. They found that boehmite gel additions increased both bending strength and thermal shock resistance of quartz-free porcelain by shifting the size of residual pores towards lower diameters and enhancing mullitization. Pseudoboehmite may be used in a porcelain paste in order to enhance the mechanical properties that may be expected from the increase in mullite content. A source for mullite in porcelain may come from the dissolution of alumina or alumina precursors saturating the porcelain glassy phase. The dissolution of alumina in alkali silicate glasses $\left(\mathrm{Na}_{2} \mathrm{O}\right.$ and $\left.\mathrm{K}_{2} \mathrm{O}\right)$ has been studied in the literature [6] by measuring the reduction of the magnitude of the enthalpy of mixing alkali silicates with alumina addition and has been attributed to the reduction of the glass nonbridging oxygen content. The aim of the present work was to study the role of the mullite phase on the mechanical properties of commercial porcelain stoneware and analyzing the resulting microstructure after systematically adding 2, 5, and $10 \mathrm{wt} \%$ pseudoboehmite.

\section{Experimental Procedure}

Raw materials used included nepheline syenite (48 wt\%), kaolin (30 wt\%), ball clay (10 wt\%), and quartz sand (12 wt\%). The pseudoboehmite was obtained using the U. G. process of the alunite [7]. This process is associated with the alkaline desulfation of the basic compounds [8]. Also, this compound can been obtained with the desulfation of the $\mathrm{Al}_{2}\left(\mathrm{SO}_{4}\right)_{3}$ using an ammonia solution. The obtained pseudoboehmite has a chemical composition of $\mathrm{Al}_{4} \mathrm{O}_{3}(\mathrm{OH})_{6}$. Furthermore, the compound was derived from the commercial sulphate with a chemical composition ( $w t \%$ ) given by $\mathrm{Al}_{2} \mathrm{O}_{3}$ (98.9010), $\mathrm{SiO}_{2}$ (0.5560), $\mathrm{CaO}$ (0.4960), $\mathrm{Fe}_{2} \mathrm{O}_{3}$ (0.0259), $\mathrm{ZnO}$ (0.0061), $\mathrm{CuO}$ (0.0053), $\mathrm{SO}_{3}$ (0.0048), $\mathrm{NiO}(0.0032)$, and $\mathrm{K}_{2} \mathrm{O}(0.0015)$ [9]. The powders were oven-dried at $100^{\circ} \mathrm{C}$ for $24 \mathrm{~h}$, and this material was ball-milled to pass a 200 mesh sieve and finally added to the slurry of porcelain by the 2, 5, and $10 \mathrm{wt} \%$. Specimens were formed by slip casting at $69 \mathrm{wt} \%$ solids loading, adjusting dispersion conditions by the use of Darvan 7, Darvan 811, and sodium silicate deflocculants [10]. Disc specimens with dimensions of $100 \times 10 \mathrm{~mm}$ were cast from properly aged slips and dried up at $110^{\circ} \mathrm{C}$ for $24 \mathrm{~h}$. Firing was done by an electric furnace up to $1250^{\circ} \mathrm{C}, 10^{\circ} \mathrm{C} / \mathrm{min}$ heating rate and $2 \mathrm{~h}$ soaking time. Bulk density was determined by water immersion procedures based on ASTM C20. Fired specimens polished and HF etched were characterized by SEM using a JEOL JSM-6300 and X-ray diffraction by a Siemens 400, CuK $\alpha 30 \mathrm{kV} 25 \mathrm{~mA}$.

The hardness $(H)$ and the fracture toughness $\left(K_{I C}\right)$ were measured (Mitutoyo MVK-E3 tester) by Vickers indentation on the polished surfaces of the sintered samples (diamond pastes of 6,3 , and $1 \mu \mathrm{m}$ ). Vickers microhardness measurements $\mathrm{HV}_{0.2}$ were made by ISO 6507 using indentation load of $1.961 \mathrm{~N}$ [11], and a series of ten measurements were

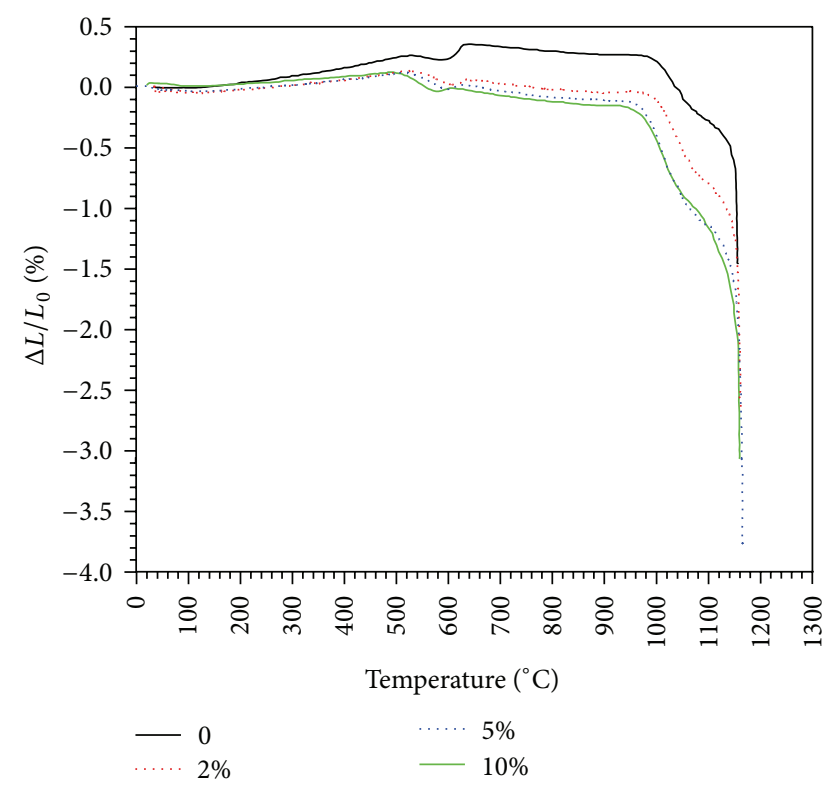

FIGURE 1: Thermodilatometry data showing higher shrinkage within the whole range of densification as pseudoboehmite additions increase.

performed to made the statistical analysis. For fracture toughness, the samples were submitted to 10 loads of $9.8 \mathrm{~N}$ for $15 \mathrm{~s}$ on each indentation. The cracks were measured using the microscope attachment on the microhardness tester immediately after indentation. Crack measurements were only made on indents that were well defined without chipping and for which the cracks did not terminate at pores. The indentation fracture toughness of the material was evaluated selecting a model included by the Palmqvist crack system [11].

The Young's modulus of the samples was measured ultrasonically using an impulse-excitation of vibration technique (Grindo-Sonic, J. W. Lemmens Inc.) according to ASTM standards C 1259-94. This method covers a dynamic determination of the elastic properties of materials at ambient temperature. Young's modulus was computed using the resonant frequency in the flexural and torsion modes of vibration. The bending strength of fired test bars was measured under a three-point bending test by a universal instron machine model 3366 according to ASTM 1161-90. The final results were taken of the average of four replications for Young's modulus, the bending strength, and the physical properties.

\section{Results and Discussion}

The synthesized pseudoboehmite with a $\mathrm{Al}_{4} \mathrm{O}_{3}(\mathrm{OH})_{6}$ composition that consisted of nanometric whiskers is known to undergo several structural thermal transformations including the $\gamma$-alumina formation at $500^{\circ} \mathrm{C}$; however, at porcelain vitrification temperatures, it is expected to dissolve in the glass and contribute to mullite formation. Figure 1 shows shrinkage behavior of porcelain samples with increasing pseudoboehmite additions. It is seen that such additions increase the shrinkage level within the whole range of 


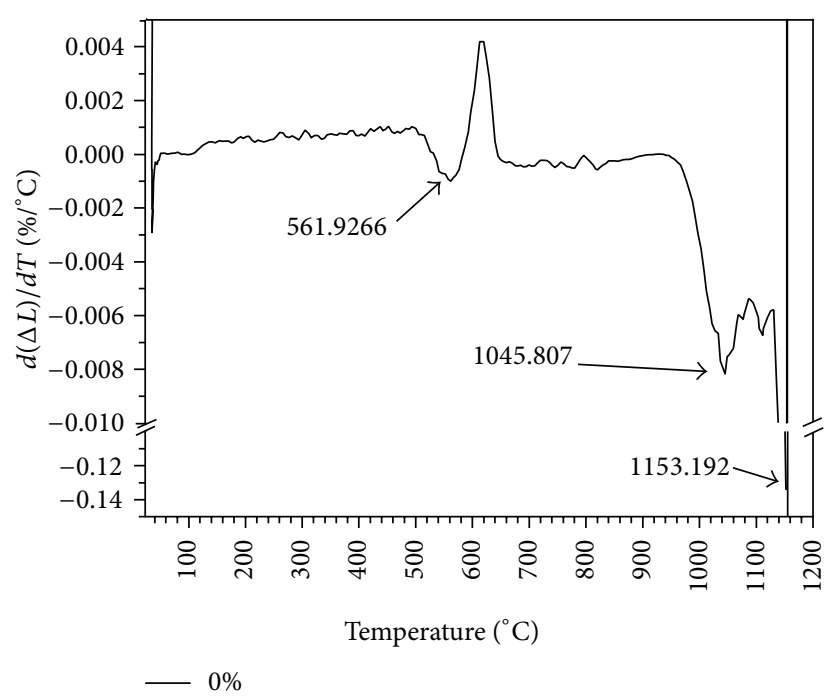

(a)

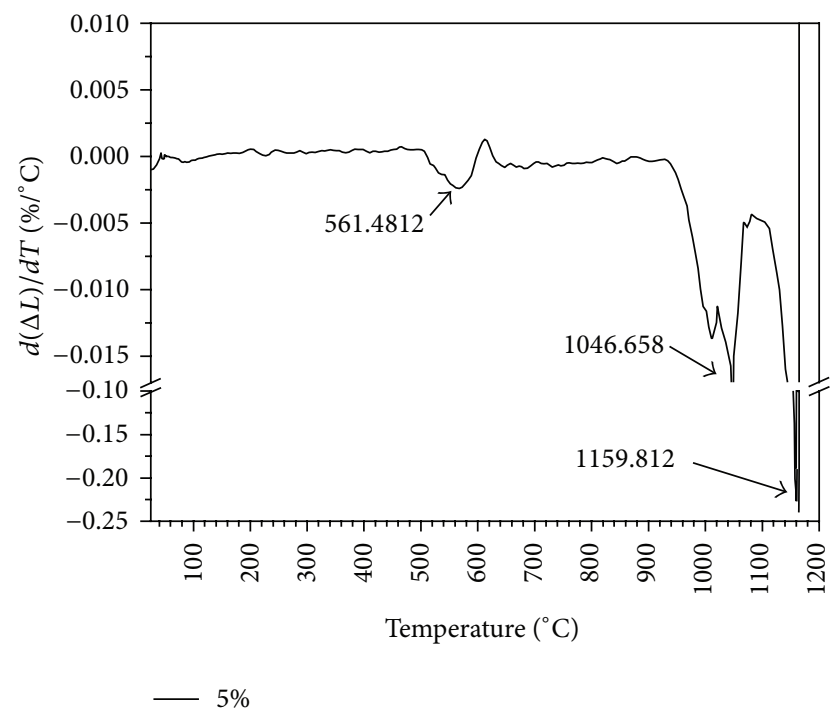

(c)

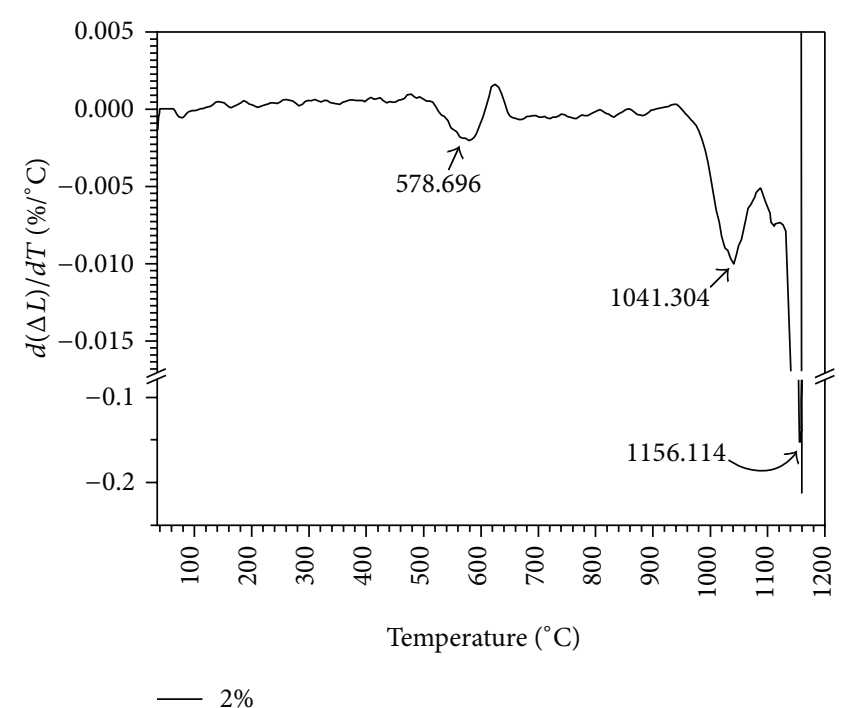

(b)

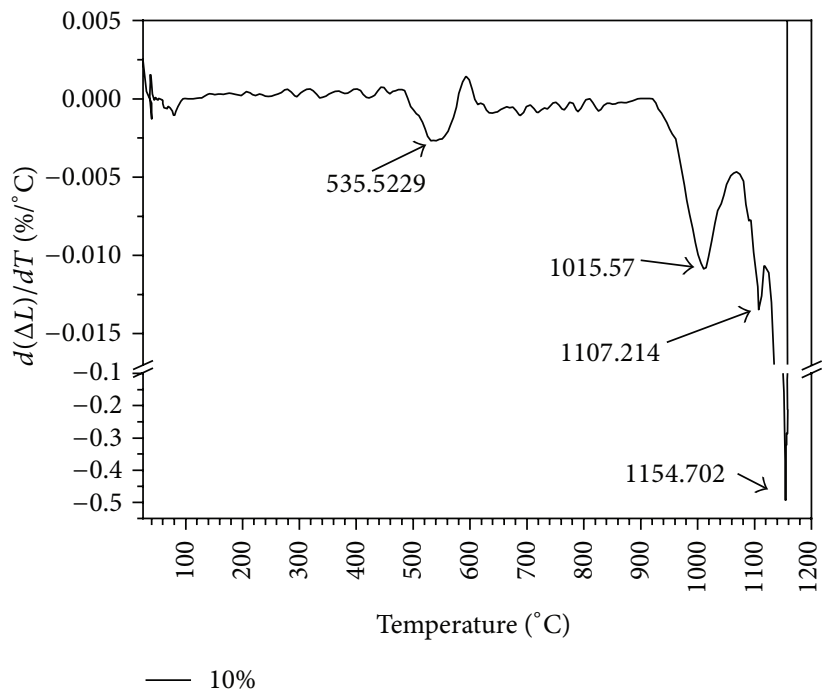

(d)

FIgURE 2: TDD curves corresponding to TD curves shown in Figure 1.

densification, implying a drastic reduction in porosity, particularly from $1100^{\circ} \mathrm{C}$ to $1160^{\circ} \mathrm{C}$ with obvious implications on strengthening. This is in agreement with the work of Belnou et al. [5] who found that pseudoboehmite additions in alumina porcelain shifted the size of residual pores towards lower diameters. It is also seen by Figure 1 that the rate of shrinkage in pseudoboehmite (PB) added samples becomes more gradual which may reduce faults and defects brought about by sudden structural rearrangements within the body.

The dilatometric curves of the compositions have been studied (Figure 2). The composition with $0 \mathrm{wt} \%$ of $\mathrm{PB}$ shows a typical behavior of the porcelain stoneware. As it can be noticed at $510-570^{\circ} \mathrm{C}$, as a result of the kaolinite dehydration and metakaolinite formation, some shrinkage is observed, followed by a volume increase at $\sim 580^{\circ} \mathrm{C}$, due to the transformation of $\alpha$-quartz to $\beta$-quartz. The compositions show considerable shrinkage at $\sim 1000^{\circ} \mathrm{C}$. The shrinkage may be associated with the liquid development, mullitization, and densification. As pseudoboehmite is added, implying lower mullitization temperature was brought about by the highly reactive pseudoboehmite sol dissolved in the glass. It therefore appears that pseudoboehmite additions may ease mullite formation.

The derived dilatometric curves have been prepared (Figure 3). These curves show the differences between the compositions. As PB is added, decomposition of clays occurs at lower temperatures. Around $1045^{\circ} \mathrm{C}$, a peak is observed in the sample without additions of $\mathrm{PB}$; this change is associated with the nucleation of primary mullite from metakaolinite. As PB is added, it can be seen that peak appears at a lower temperature. Samples with additions of $5 \mathrm{wt} \%$ and $10 \mathrm{wt} \%$ of $\mathrm{PB}$, the third peak appears associated with the formation 
TABLE 1: Experimental physical and mechanical properties.

\begin{tabular}{|c|c|c|c|c|c|c|c|c|}
\hline Pseudoboehmite addition ( $w \mathrm{t} \%)$ & $\begin{array}{l}\text { Firing } \\
\text { Temp. } \\
\left({ }^{\circ} \mathrm{C}\right)\end{array}$ & Sample & $\begin{array}{c}\text { Modulus } \\
\text { of rupture } \\
(\mathrm{MPa})\end{array}$ & $\begin{array}{c}\text { Bulk } \\
\text { density } \\
\left(\mathrm{g} / \mathrm{cm}^{3}\right)\end{array}$ & $\begin{array}{l}\text { Young's } \\
\text { modulus } \\
(\mathrm{GPa})\end{array}$ & $\begin{array}{c}\text { Vickers } \\
\text { micro- } \\
\text { hardness } \\
(\mathrm{GPa})\end{array}$ & $\begin{array}{c}\text { Fracture } \\
\text { toughness } \\
K_{I C} \\
\left(\mathrm{MPa} \cdot \mathrm{m}^{1 / 2}\right)\end{array}$ & $\begin{array}{c}\text { Porosity } \\
(\%)\end{array}$ \\
\hline \multirow{3}{*}{2} & 1150 & 1 & 92 & 2.1 & 49.5 & 6.1 & 1.4 & 5.6 \\
\hline & 1200 & 4 & 56.9 & 2.0 & 57.5 & 7.0 & 1.6 & 6.6 \\
\hline & 1250 & 7 & 42.7 & 1.9 & 64.34 & 6.8 & 1.7 & 7.6 \\
\hline \multirow{3}{*}{5} & 1150 & 2 & 81.2 & 2.2 & 40.5 & 6.8 & 1.5 & 5.1 \\
\hline & 1200 & 5 & 94.5 & 2.2 & 60.2 & 6.8 & 1.7 & 7.8 \\
\hline & 1250 & 8 & 107.4 & 2.1 & 62.2 & 6.9 & 1.5 & 7.5 \\
\hline \multirow{3}{*}{10} & 1150 & 3 & 76.3 & 2.0 & 32.8 & 6.4 & 1.2 & 7.9 \\
\hline & 1200 & 6 & 70.2 & 2.1 & 53 & 7.1 & 1.5 & 9.4 \\
\hline & 1250 & 9 & 101.8 & 2.0 & 56.8 & 6.4 & 1.5 & 12.6 \\
\hline M. Dondi et al. [12] & 1200 & & 50 & $2.4-2.5$ & 79 & 6.5 & 1.2 & \\
\hline Zanelli et al. [4] & 1220 & & 42 & $2.2-2.4$ & & & 1.1 & $4-12.8$ \\
\hline
\end{tabular}

TABLE 2: Analysis of variance of bulk Density and porosity.

\begin{tabular}{|c|c|c|c|c|c|c|c|c|c|c|c|}
\hline \multicolumn{6}{|c|}{ Bulk density } & \multicolumn{6}{|c|}{ Porosity } \\
\hline Factor & SS & $\mathrm{df}$ & MS & $F$ & $P$ & Factor & SS & df & MS & $F$ & $P$ \\
\hline $\begin{array}{l}\text { Temperature } \\
\mathrm{L}+\mathrm{Q}\end{array}$ & 0.02 & 2.00 & 0.01 & 5.87 & 0.06 & $\begin{array}{c}\text { Temperature } \\
\mathrm{L}+\mathrm{Q}\end{array}$ & 13.88 & 2.00 & 6.94 & 7.05 & 0.05 \\
\hline $\begin{array}{l}\mathrm{PB}(\%) \\
\mathrm{L}+\mathrm{Q}\end{array}$ & 0.05 & 2.00 & 0.02 & 11.34 & 0.02 & $\begin{array}{c}\mathrm{PB}(\%) \\
\mathrm{L}+\mathrm{Q}\end{array}$ & 21.74 & 2.00 & 10.87 & 11.04 & 0.02 \\
\hline Error & 0.01 & 4.00 & 0.00 & & & Error & 3.94 & 4.00 & 0.98 & & \\
\hline Total & 0.08 & 8.00 & & & & Total & 39.55 & 8.00 & & & \\
\hline
\end{tabular}

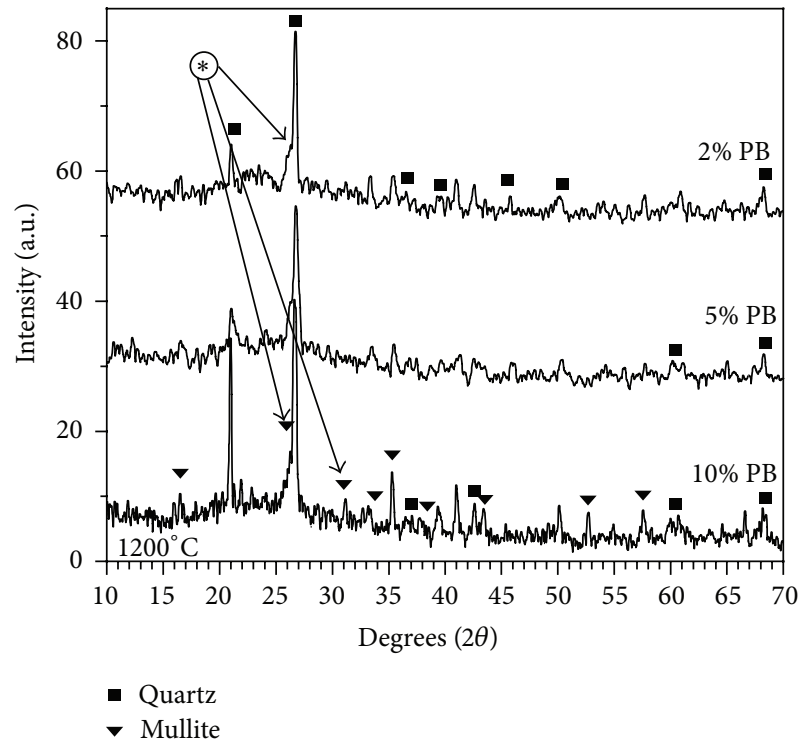

FIGURE 3: X-ray diffraction patterns of experimental porcelain compositions fired at $1200^{\circ} \mathrm{C}$ for boehmite additions $(2,5,10 \mathrm{wt} \%)$. ${ }^{*}$ Note moderate increase in the mullite peaks intensity.

of secondary mullite, attributable to the high reactivity of PB particles with the liquid phase. The importance of these curves is that the position of their minimums values indicates the reactivity of the various compositions. The sequence of reactivity by increasing temperatures is $10 \%>5 \%>2 \%>0 \%$. The reactivity of the composition is due to the corresponding additions of PB.

This assumption was confirmed by the XRD results of samples, sintered at $1200^{\circ} \mathrm{C}$ (Figure 3). Mullite phase increases moderately with added pseudoboehmite as shown in Figure 3 by $\mathrm{X}$ ray diffraction. The aspect ratio of the acicular mullite also increases with both pseudoboehmite additions and temperature as shown by SEM in Figure 4. In general it is seen that mullite needles coarsen, leading to a smaller number of larger needles. Figure 5 shows a fracture surface in a $10 \mathrm{wt} \%$ pseudoboehmite sintered at $1150^{\circ} \mathrm{C}$ specimen where an intergranular type of crack that propagates among primary mullite is being stopped by a cluster of nanometric mullite $\left(2 / 3 \mathrm{Al}_{2} \mathrm{O}_{3} / \mathrm{SiO}_{2}\right)$ crystals as determined by EDX.

The statistical treatment of physical and mechanical measurements has enabled the elaboration of mathematical models and permitted not only to simulate the mechanical behavior, but also to evaluate the contribution of the various experimental parameters involved in. By ANOVA analysis, the factors with statistical relevance have been defined, while by least squares method their coefficients in the mathematical model have been calculated. Table 1 lists average values of measured physical and mechanical properties obtained for three replications. The results of experiments designed in Table 1 were analyzed using ANOVA method and the results are in Tables 2 and 3. Based on the data of Table 2, 


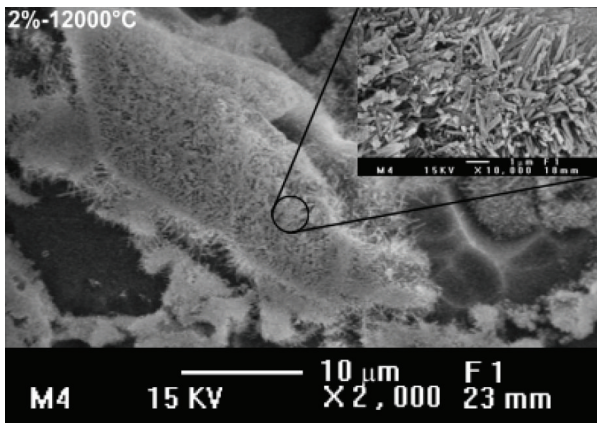

(a)

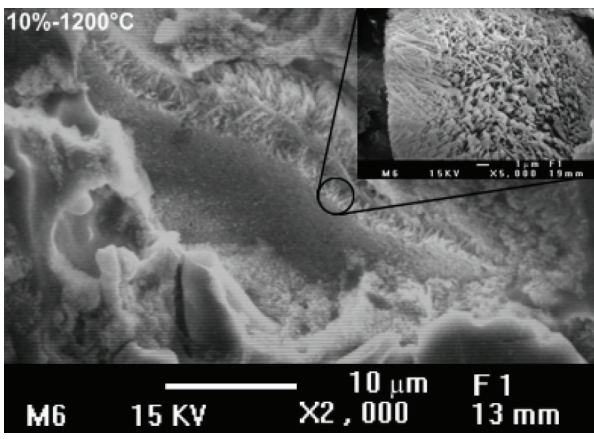

(c)

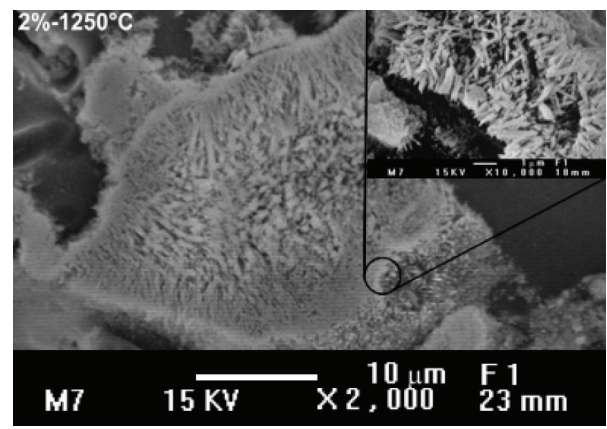

(b)

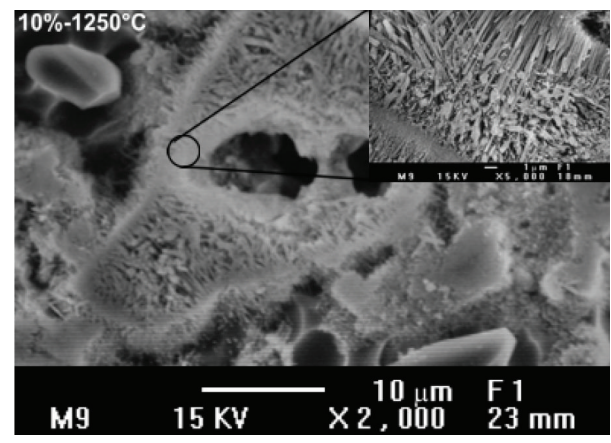

(d)

FIGURE 4: SEM micrographs of etched surfaces showing acicular mullite formation. Note increasing aspect ratio of mullite needles depending on both temperature (left to right) and composition (top to bottom).

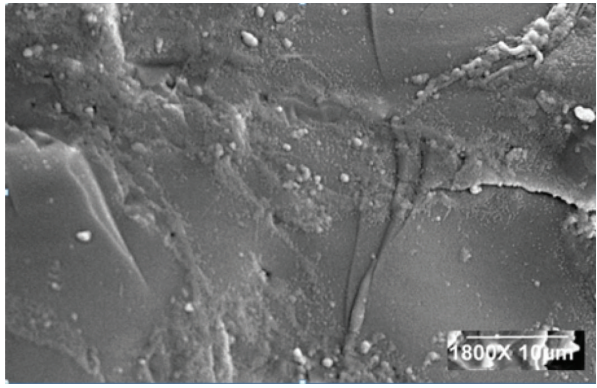

(a)

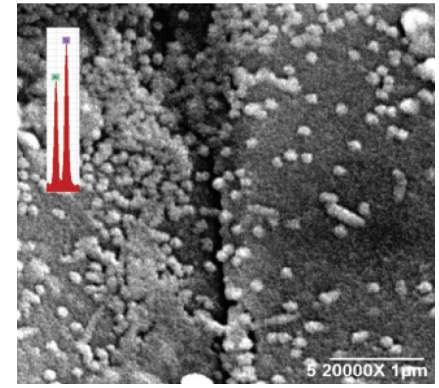

(b)

FIGURE 5: SEM micrographs porcelain stoneware fracture surfaces. (a) A crack stops at a spot of high mullite concentration. (b) Intergranular crack propagates among primary nanometric mullite (2/3 Al203/Si02) crystals.

TABLE 3: Analysis of variance of Young's modulus and Vickers microhardness.

\begin{tabular}{|c|c|c|c|c|c|c|c|c|c|c|c|}
\hline \multicolumn{6}{|c|}{ Young's modulus } & \multicolumn{6}{|c|}{ Vickers microhardness } \\
\hline Factor & SS & $\mathrm{df}$ & MS & $F$ & $P$ & Factor & SS & $\mathrm{df}$ & MS & $F$ & $P$ \\
\hline $\begin{array}{l}\text { Temperature } \\
\mathrm{L}+\mathrm{Q}\end{array}$ & 679.92 & 2.00 & 339.96 & 26.71 & 0.00 & $\begin{array}{c}\text { Temperature } \\
\mathrm{L}+\mathrm{Q}\end{array}$ & 0.34 & 2.00 & 0.17 & 1.58 & 0.31 \\
\hline $\begin{array}{l}\mathrm{PB}(\%) \\
\mathrm{L}+\mathrm{Q}\end{array}$ & 145.48 & 2.00 & 72.74 & 5.72 & 0.07 & $\begin{array}{c}\mathrm{PB}(\%) \\
\mathrm{L}+\mathrm{Q}\end{array}$ & 0.09 & 2.00 & 0.04 & 0.42 & 0.69 \\
\hline Error & 50.90 & 4.00 & 12.73 & & & Error & 0.43 & 4.00 & 0.11 & & \\
\hline Total & 876.30 & 8.00 & & & & Total & 0.86 & 8.00 & & & \\
\hline
\end{tabular}




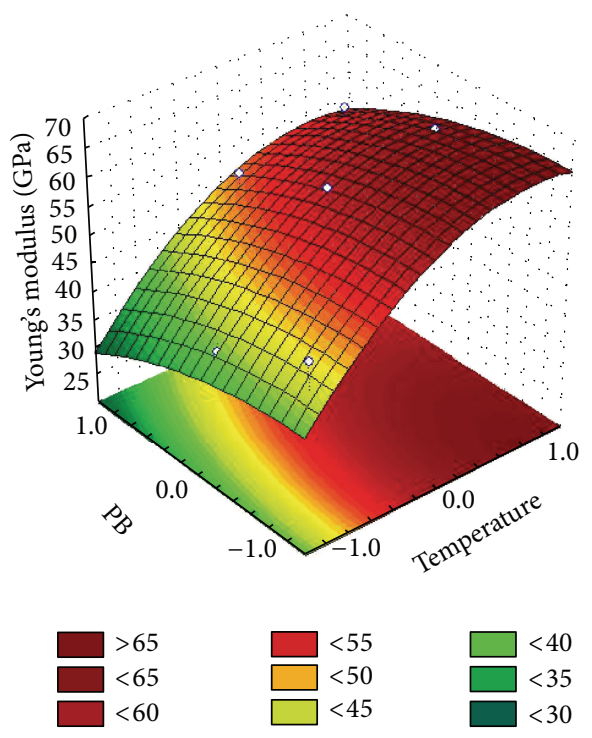

FigURE 6: 3D surface response of Young's modulus versus pseudoboehmite additions and temperature.

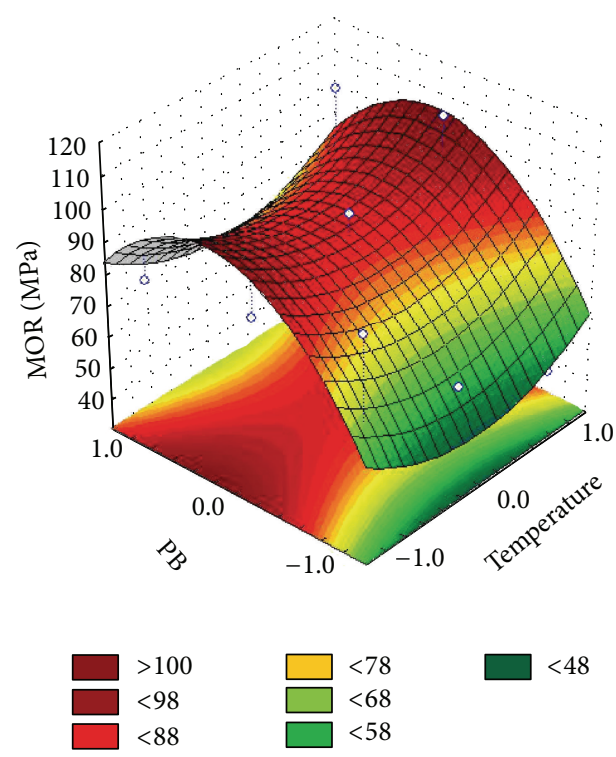

FIGURE 7: 3D surface response of modulus of rupture versus pseudoboehmite additions and temperature.

the pseudoboehmite and the temperature have statistical significance, the significance of the factors were obtained by comparing the $F$ calculated value versus the $F$ tabulated value in the Fisher-Snedecor distribution; if the $F$ calculated values are higher than the $F$ tabulated values (at the required level of significance) is considered to exist statistical significance, all the $F$ values presented in Table 2 are higher than the tabulated. Both the temperature and the additions of $\mathrm{PB}$ have a positive effect on the bulk density and porosity. This is consistent with the stated above in dilatometric curves, where it was observed that the formation of glassy phase was obtained at higher temperatures and additions of $\mathrm{PB}$, enabling that the liquid phase can surround the clay relicts and quartz,

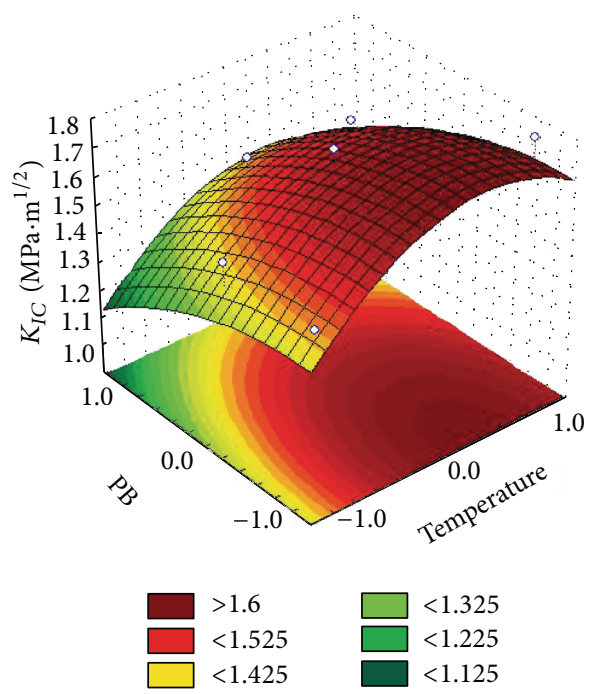

FIGURE 8: 3D surface response of fracture toughness versus pseudoboehmite additions and temperature.

and the achieving of a higher density. Increased porosity was consistent with the published results for Belnau et al. [5], limiting PB additions to the mixture of porcelain.

Table 3 shows that the independent variables have a statistical significance for the Young's modulus, but for the Vickers microhardness they do not have a statistical significance. The temperature and the additions of $\mathrm{PB}$ have a positive effect on Young's modulus. At higher temperature and additions of PB, the properties of modulus of elasticity increase (Figure 6). For Vickers microhardness, temperature and $\mathrm{PB}$ additions have no significant effect; this has important implications for improving the mechanical properties since it does not want to make more fragile materials. The modulus of rupture varies with both temperature and pseudoboehmite additions. The highest modulus (108 MPa) occurs for the $5 \%$ and $10 \%$ of pseudoboehmite additions, which is an important increase in strength as compared to samples without pseudoboehmite additions and those reported in the literature [12] that present about half of the latter value $(50 \mathrm{Mpa})$. Regarding the effect of the temperature on the modulus of rupture, the higher modulus measurements (108 and $102 \mathrm{MPa}$ ) correspond to samples with higher levels of pseudoboehmite (5 and $10 \mathrm{wt} \%$ ) heated up to $1250^{\circ} \mathrm{C}$. On the contrary specimens that contain $2 \%$ pseudoboehmite and therefore less refractoriness present low strength $(43 \mathrm{MPa})$ at the same temperature $\left(1250^{\circ} \mathrm{C}\right)$. This entire phenomenon can be observed in Figures 6 and 7. Fracture toughness in pseudoboehmite containing samples almost doubles the value 1.2 presented by pseudoboehmite free specimens as shown in Table 1. The fracture toughness showed some variation both with sintering temperature and pseudoboehmite additions as shown in Figure 8. The highest value of $\mathrm{K} 1 \mathrm{C}$ was obtained with $5 \% \mathrm{~PB}$ and sintering at $1200^{\circ} \mathrm{C}$, and this is a consequence of the quantity of crystalline phase and lower porosity, limiting the propagation of Griffith cracks.

By analyzing the three graphs of surface, it can be seen that the higher areas are reached at a temperature of $1200^{\circ} \mathrm{C}$ 
and 5\% PB additions. The combination of these factors achieves a synergistic effect between the amount of liquid present and $\mathrm{PB}$ particles, and this is a consequence of the highest density of the sample, the decrease in the porosity, and the extra mullitization promoted by the additions of $\mathrm{PB}$ that creates a barrier that stops the cracks.

\section{Conclusions}

The high reactivity of pseudoboehmite sol additions presumably increased the amount of alumina dissolved in the glass, thereby increasing moderately the precipitated mullite phase content. It appears that strengthening of the porcelain may be caused by a dispersion-strengthening mechanism rather than by a substantial increase in the mullite phase content. Primary mullite nanometric crystal clusters were shown to limit the intergranular crack propagation, in agreement with the dispersion-strengthening hypothesis whereby dispersed particles limit the size of Griffith flaws leading to increased strength. Also, pseudoboehmite additions allowed the reinforcement of green bodies producing less body defects and higher densification.

\section{Conflict of Interests}

The authors declare that there is no conflict of interests regarding the publication of this paper.

\section{Acknowledgment}

The authors acknowledge the financial support of the Investigación Científica y Desarrollo Tecnológico del Sistema Nacional de Institutos Tecnológicos, México.

\section{References}

[1] W. M. Carty and U. Senapati, "Porcelain-raw materials, processing, phase evolution, and mechanical behavior," Journal of the American Ceramic Society, vol. 81, no. 1, pp. 3-20, 1998.

[2] O. I. Ece and Z.-E. Nakagawa, "Bending strength of porcelains," Ceramics International, vol. 28, no. 2, pp. 131-140, 2002.

[3] H.-Y. Lu, W.-L. Wang, W.-H. Tuan, and M.-H. Lin, "Acicular mullite crystals in vitrified kaolin," Journal of the American Ceramic Society, vol. 87, no. 10, pp. 1843-1847, 2004.

[4] C. Zanelli, M. Dondi, G. Guarini, M. Raimondo, and I. Roncarati, "Influence of strengthening components on industrial mixture of porcelain stoneware tiles," Key Engineering Materials, vol. 264-268, pp. 1491-1494, 2004.

[5] F. Belnou, D. Goeuriot, P. Goeuriot, and F. Valdivieso, "Nanosized alumina from boehmite additions in alumina porcelain: 1 . Effect on reactivity and mullitisation," Ceramics International, vol. 30, no. 6, pp. 883-892, 2004.

[6] P. J. Lezzi and M. Tomozawa, "Effect of alumina on enthalpy of mixing of mixed alkali silicate glasses," Journal of NonCrystalline Solids, vol. 357, no. 10, pp. 2086-2092, 2011.

[7] W. X. López, "Three methods to produce alumina from alunite," in Light Metals, vol. 2, pp. 49-58, American Institute of Mining, Metallurgical and Petroleum Engineers, New York, NY, USA, 1977.
[8] H. Juárez-M, J. M. Martínez-R, and J. M. Ruvalcaba-L, "Obtención y caracterización de pseudoboehmita a partir de sulfato de aluminio comercial," in IV Congreso Iberoamericano de Química Inorgánica y XI Congreso Mexicano de Química Inorgánica, pp. 256-260, Guanajuato, México, 1993.

[9] S. D. de la Torre, A. Kakitsuji, H. Miyamoto et al., "Seeding with $\alpha$-alumina for transformation and densification of boehmitederived $\gamma$ and $\delta$-alumina by spark plasma sintering," Ceramic Transactions, vol. 94, pp. 83-89, 1999.

[10] O. Aguilar-García, S. Bribiesca-Vazquez, and J. Zarate-Medina, "Mixture design to optimize the amount of deflocculants in aqueous porcelain precursor suspensions," Journal of Ceramic Processing Research, vol. 10, no. 2, pp. 125-128, 2009.

[11] O. Aguilar-García, S. Bribiesca-Vazquez, and J. Zárate-Medina, "Evaluation of hardness and fracture toughness in a porcelain stoneware with pseudoboehmite additions," Journal of Ceramic Processing Research, vol. 10, no. 1, pp. 37-42, 2009.

[12] M. Dondi, M. Raimondo, C. Zanelli, and P. M. T. Cavalcante, "Sintering mechanisms of porcelain stoneware tiles," in Proceedings of International Conference on the Science, Technology \& Applications of Sintering (SINTERING '03), 2003. 

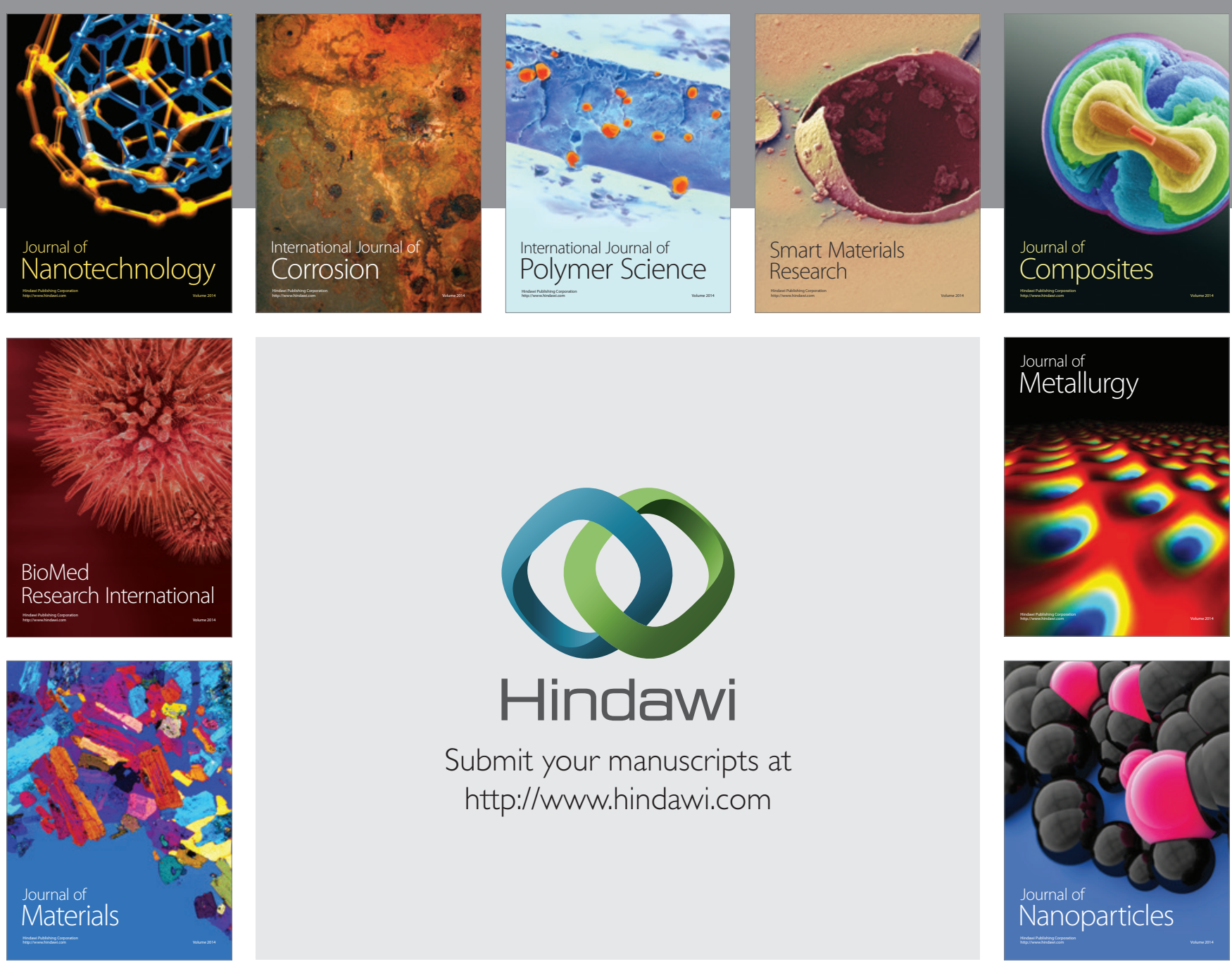

Submit your manuscripts at http://www.hindawi.com
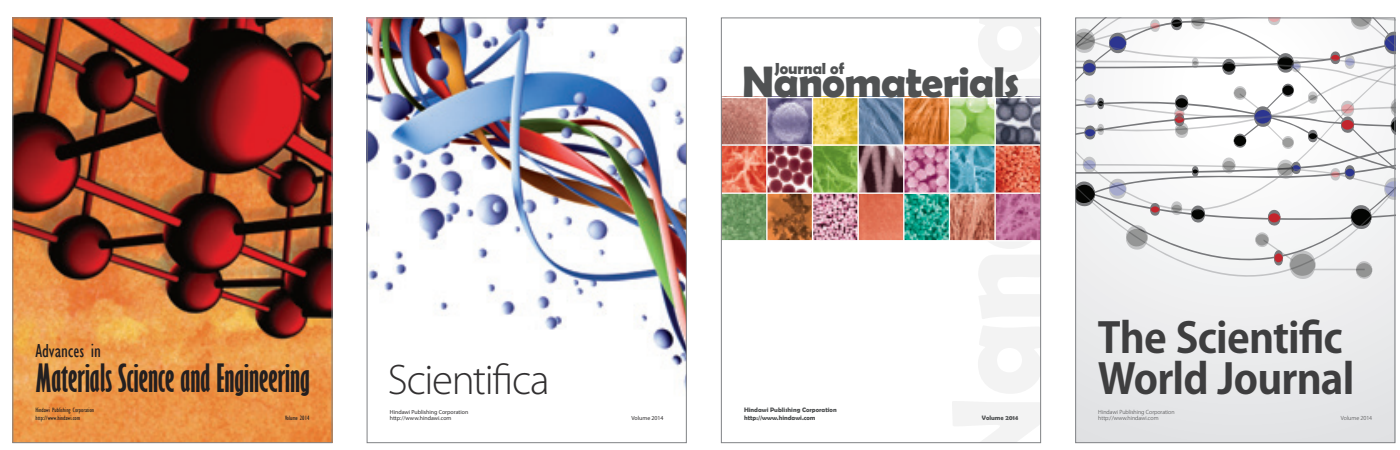

\section{The Scientific World Journal}
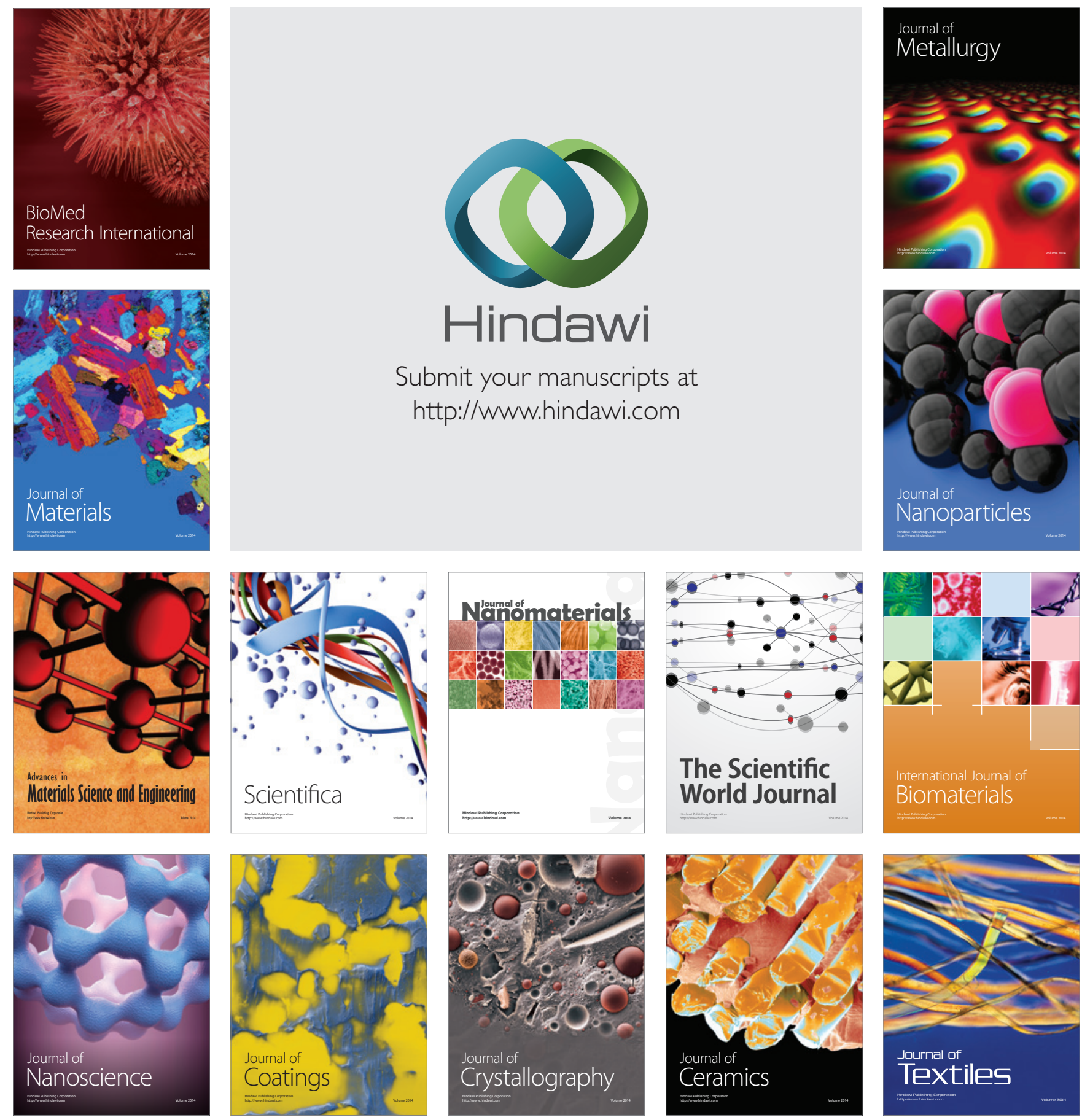